\title{
PERSPEKTIF TEOLOGIS TERHADAP ETIKA BISNIS KRISTEN
}

\author{
Dr. Malik Bambangan \\ Sekolah Tinggi Teologi Injili Arastamar Jakarta, \\ malikbambangan@gmail.com
}

\begin{abstract}
The perspective of the Christian faith in understanding the world of work is the same when it is involved in the work. In the business world, according to some opinions it is solely for profit. In the perspective of the Christian faith, business is a manifestation of one's faith responsibilities towards God and others. The perspective of the Christian faith in the business world must be understood as a service. Therefore, ethical business ethics in the perspective of Christian faith need to be understood and implemented based on the Word of God.
\end{abstract}

Keywords: Faith, Christianity, Ethics, Business

\begin{abstract}
Abstrak: Sudut pandang iman Kristen dalam memahami dunia kerja adalah sama ketika terlibat di dalam pekerjaan tersebut. Dalam dunia bisnis menurut beberapa pendapat adalah semata-mata bertujuan mencari untung. Dalam perspektif iman Kristen melihat bisnis sebagai perwujudan tanggungjawab iman seseorang terhadap Tuhan dan sesama. Perspektif iman Kristen terhadap dunia bisnis mesti dipahami sebagai suatu pelayanan. Oleh sebab itu etika berbinsnis dalam perpektif iman Kristen perlu dipahami dan dijalankan dengan berdasar pada Firman Tuhan.

Kata Kunci: $\quad$ Iman, Kristen, Etika, Bisnis
\end{abstract}

\section{Pendahuluan}

Berbicara tentang bisnis atau lebih disederhanakan sebagai suatu usaha, tentu kita akan memandang dari beberapa sisi. Sisi pertama orang akan berkata bahwa bisnis itu baik, namun sisi yang kedua orang akan berbicara bahwa bisnis itu kotor. Apakah benar demikian? Dalam kesempatan ini penulis akan membahas sedikit mengenai etika bisnis orang Kristen dilihat dari sudut pandang Alkitab. Berdasarkan dari dua anggapan di atas, maka akan muncul pertanyaan bahwa, apakah boleh orang Kristen itu berbisnis? Berbicara tentang etika adalah berbicara tentang benar dan salah, boleh atau tidaknya sesuatu yang dilakukan oleh manusia. Oleh sebab itu Marx menyatakan bahwa, setiap tindakan manusia adalah hasil suatu keputusan yang dipilihnya, entah itu tindakan yang 
terlihat secara kasat mata ataupun tidak.1 Di sinilah perlunya ada etika yang mengatur tindakan manusia tersebut dalam melakukan kegiatan bisnis mereka berdasarkan kebenaran firman Tuhan.

\section{Metode Penelitian}

Penelitian ini menggunakan pendekatan kualitatif, secara khusus kajian pustaka. Pendekatan ini diambil untuk memperoleh pemahaman kualitatif yang valid dan komprehensif bagi topik yang dibahas dalam penelitian ini.

\section{Pembahasan: Definisi Etika}

Etika

Kata etika berasal dari bahasa Yunani yakni ethos, yang artinya adalah kebiasaan, adat istiadat dan kesusilaan.2 Menurut Daniel Ronda, dalam mengutip Verkuyl menyatakan bahwa etika sama dengan moral yang membahas dan menilai suatu perbuatan yang baik dan jahat. Jadi etika lanjut Ronda, bukanlah suatu pengertian deskriptif yang hanya menjelaskan suatu fenomena, melainkan juga memberikan penilaian tentang salah dan benar, baik dan jahat.3 Marx menyatakan bahwa, Etika adalah ilmu yang mempelajari nilai-nilai dan prinsip-prinsip yang membentuk tingkah laku. Istilah etika ini beragam dan mempunyai prinsip yang berbeda-beda dalam suatu tatanan masyarakat.4 Adapun ruang lingkup pembahasan dalam bidang etika adalah membahas mengenai benar atau salah, wajar atau tidak wajar, jujur atau tidak jujur, tepat atau tidak, dan bertanggung jawab atau tidak. Pengertian yang lebih rinci oleh J.A. Boersema yang mengutip Douma menuliskan, etika adalah pertimbangan-pertimbangan tentang kelakuan moril, yang dapat digambarkan sebagai kelakuan yang; 1) manusiawi, 2) bernorma, 3) dipandang di bawah aspek baik-buruk, 4) berkaitan dengan motivasi, 5) disertai dengan emosi, 6) di mana kebajikan yakni tabiat baik merupakan sikap dasar, 7) dan yang tertuju kepada nilai-nilai yang tertinggi.5

\section{Bisnis}

Bisnis adalah usaha atau proses pertukaran produk atau jasa dalam rangka pencapaian nilai tambah. Karena sekarang kita membahas topik etika bisnis, maka kita akan lebih fokus membahas hal tersebut berdasarkan terang firman Tuhan. Adapun cakupan daripada etika bisnis ini adalah membahas mengenai masalah-masalah dalam konteks bisnis yang terkait dengan standar moral. Etika bisnis ini juga berbicara

1 Dorothy Irene Marx, Etika Hamba Tuhan, (Jakarta:Obor Mitra Indonesia, 2001), Vii

2 J. Douma, Kelakuan Yang Bertanggung Jawab, (Jakarta: BPK. Gunung Mulia, 2007), 2

3 Daniel Ronda, Leadership Wisdom, (Bandung: Kalam Hidup, 2011), 88

4 Marx, Etika Hamba Tuhan, 1

5 J.A.Boersema, Diktat Etika Kristen, pada program pasca sarjana SETIA Jakarta, 2008, 4. Hal ini dipandang layak oleh penulis untuk menjadi pegangan bagi orang Kristen dalam memahami dunia bisnis dalam pandangan iman Kristen. 
mengenai integritas antara mencapai nilai tambah tetap berkembang sejalan dengan standar-standar moral yang melandasi usaha manusia mencapai keutuhan dan perkembangan segala aspek.6 Inilah fokus pembahasan dalam etika bisnis.

\section{Etika Bisnis}

Pemahaman tentang etika Kristen akan memberikan pemahaman yang dasar kepada kita dalam memahami definisi etika bisnis orang Kristen. Menurut K. Shilder (1890-1952), Etika Kristen adalah ilmu teologi yang menyelidiki ukuran-ukuran yang tetap, masyarakat-masyarakat yang berganti-ganti dan kewajiban manusia untuk menentukan kehendaknya taat dalam situasi kondisi yang aktual dan konkret terhadap kehendak Allah yang dinyatakan.7 Lalu bagaimana dengan definisi atau pengertian daripada etika bisnis itu sendiri? Apakah yang perlu diperhatikan yang menjadi pokok permasalahan dalam etika bisnis itu? Etika bisnis merupakan studi yang dikhususkan mengenai moral yang benar dan salah. Studi ini berkonsentrasi pada standar moral sebagaimana diterapkan dalam kebijakan, institusi, dan perilaku bisnis (Velasquez, 2005).8 Etika bisnis dalam perusahaan memiliki peran yang sangat penting, yaitu untuk membentuk suatu perusahaan yang kokoh dan memiliki daya saing yang tinggi serta mempunyai kemampuan menciptakan nilai (value-creation) yang tinggi, diperlukan suatu landasan yang kokoh. Secara sederhana yang dimaksud dengan etika bisnis adalah cara-cara untuk melakukan kegiatan bisnis, yang mencakup seluruh aspek yang berkaitan dengan individu, perusahaan, industri dan juga masyarakat. Kesemuanya ini mencakup bagaimana kita menjalankan bisnis secara adil, sesuai dengan hukum yang berlaku, dan tidak tergantung pada kedudukan individu ataupun perusahaan di masyarakat.

Etika bisnis lebih luas dari ketentuan yang diatur oleh hukum, bahkan merupakan standar yang lebih tinggi dibandingkan standar minimal ketentuan hukum, karena dalam kegiatan bisnis seringkali kita temukan wilayah abu-abu yang tidak diatur oleh ketentuan hukum.

\section{Pembahasan: Perspektif Teologis tentang Etika Bisnis}

Dalam pembahasan ini kita akan selalu melihat dalam sudut pandang teologis tentang etika Bisnis. Etika Kristen melihat bisnis sebagai suatu penatalayanan ekonomi bagi sesama. Hal ini dapat dipahami akan pentingnya dasar dan tujuan dalam berbisnis bagi orang Kristen. Sebagaimana pendapat Alexander Hill menyatakan bahwa, etika Kristen tidak menerima pemisahan antara pekerjaan dan kehidupan. Kita seharusnya

${ }_{6}$ Robby I. Chandra, Etika Dunia Bisnis, (Yogyakarta: Kanasius, 1995), 43

7 Douma, Kelakuan..., 38

8 Sumber: http://handyleonardoetikabisnis. blogspot.com/2012/09/pengertian-etika-etikabisnis-dan. html, disunting oleh Malik Darius Bambangan, pada tgl. 21-8-2014 
sama di manapun kita berada, apapun yang kita lakukan.9 Itu artinya bahwa bisnis bagi orang percayapun terus berpatokan pada etika Kristen. Bisnis adalah merupakan salah satu cara yang dipakai manusia untuk mencari keuntungan demi mendapatkan kekayaan. Dengan berbisnis orang dapat meraih keberhasilan secara materi. Itulah sebabnya ada orang yang berpendapat bahwa ada suatu usaha yang hanya mencari untung dan orang bisnis itu atau businessman itu adalah orang kaya (banyak duit). Seperti pada penjelasan Anton Wuisan menyatakan, Bisnis dianggap sebagai satu kegiatan yang semata-mata berorientasi pada upaya mencari keuntungan dan menyelamatkan keuntungan dengan pelbagai cara.10 Menyelamatkan keuntungan di sini sama halnya dengan menimbun keuntungan agar semakin banyak harta bendanya. Bagaimana caranya supaya dapat memperoleh hal yang demikian? Hal ini membutuhkan suatu keahlian khusus dalam mengelolanya sehingga dapat berhasil dengan baik. Dalam dunia bisnis dibutuhkan hikmat atau pengetahuan yang cukup bisnis atau usaha tersebut sehingga menjadi maju dan memberikan keuntungan kepadanya pemiliknya. Bagaimana dengan kekristenan, apakah diperbolehkan berbisnis atau tidak? Untuk menjawab hal itu, maka perlu kita melihatnya dalam terang Alkitab.

\section{Dasar Alkitab}

Kita sudah membahas mengenai definisi etika dan bisnis. Pada dasarnya bahwa bisnis adalah suatu kegiatan yang dilakukan oleh manusia untuk memenuhi kebutuhannya bahkan lebih dari cukup. Itu artinya bahwa dalam bisnis itu sendiri menuntut para pemerannya untuk bekerja. Dalam Alkitab tentang bekerja adalah merupakan kehendak Allah. Dan bekerja dalam Alkitab adalah merupakan persekutuan manusia dengan Tuhan, dimana manusia menjadi kawan sekerja Allah di bumi ini. Dasarnya di mana? Banyak orang mengatakan termasuk orang Kristen bahwa kita bekerja karena Adam sudah melanggar perintah Allah. Coba kalau tidak melanggar saat itu, pasti kita akan hidup enak, tidak setengah mati bekerja seperti ini. Ini adalah pendapat yang keliru, dan juga penafsiran Alkitab yang salah. Sebelum manusia jatuh ke dalam dosapun, sebenaranya Allah sudah memberikan tugas dan tanggung jawab kepada manusia untuk mengusahakan dan memelihara taman Eden tersebut (Kej. 2:15). Bahkan pada ayat sebelumnya dalam Kejadian 1:26-28 di sana ada kata berkuasa atas ikan-ikan di laut dan burung-burung.... Ini mengindikasikan bahwa manusia diberi mandat untuk bekerja dan tugas itu diulang lagi dalam Kejadian 2:15 dalam cakupan yang lebih luas.

Jadi bekerja adalah merupakan panggilan Allah bagi manusia untuk bekerja bukan sebagai kutukan karena manusia sudah jatuh ke dalam dosa. Daniel Ronda menyatakan bahwa, sebelum kejatuhan, pekerjaan adalah suatu anugerah dan panggilan dari Allah sendiri. Sesudah kejatuhan, pekerjaan itu tetap merupakan anugerah dan panggilan. 
Namun akibat dosa, maka pekerjaan itu dilakukan dengan penuh persaingan.11 Tidak ada dasar Alkitab bagi kita bahwa manusia tidak boleh bekerja, malahan Alkitab berkata kepada yang malas untuk belajar kepada semut, karena akibat dari kemalasan adalah kemiskinan (Amsal 6:6-11). Tangan yang lamban menjadikan miskin, tetapi tangan yang rajin menjadikan kaya (Amsal 10:4). Demikian juga dalam Perjanjian Baru oleh Paulus mengingatkan akan pentingnya bekerja demi menunjang kelangsungan hidup. Bahkan Paulus tegaskan bahwa jika ada yang tidak mau bekerja janganlah ia makan (II Tes. 3:6$15)$.

Bagi orang Kristen dalam dunia bisnispun harus tetap berpedoman pada Alkitab. Daniel Ronda mengatakan bahwa adalah penting bagi orang percaya bahwa Alkitab menjadi satu-satunya penuntun dalam kehidupannya, dan termasuk dalam melakukan kegiatan bisnis.12 Hal ini sebagai warning light bagi setiap pengusaha atau pebisnis Kristen untuk tidak menjadikan bisnisnya sebagai ilah dan melupakan Tuhan yang telah memberikan kekayaan kepada mereka (Ul.8:11-20).

\section{Motivasi Pebisnis Kristen}

Motivasi businessman ada bermacam-macam. A. Sonny Keraf mengatakan, "kebanyakan diantaranya terjun ke dunia bisnis hanya dengan motivasi dasar untuk mencari keuntungan dan memperoleh tingkat hidup yang mencukupi secara material." 13 Kegiatan bisnis sangat membantu usaha-usaha pemenuhan kebutuhan masyarakat. Bisnis ini meliputi semua aspek kegiatan untuk menyalurkan barang-barang melalui usaha produktivitas, usaha jual beli.14 Jadi melalui bisnis ini orang bisa menjadi kaya karena ada usaha yang memberi keuntungan. Tujuan untuk mendapatkan keuntungan inilah yang menjadi motivasi mereka dalam berbisnis.15 Lalu bagaimana sebenarnya motivasi pemeran bisnis Kristen sehingga tetap menjaga keutuhan imannya tanpa dipengaruhi oleh kecurangan dan tindakan tidak terpuji dalam berbisnis? Motivasi pemeran bisnis orang Kristen adalah motivasi yang murni, jujur dan adil. Ronda menyatakan, dunia bisnis tidak selalu jujur. Oleh karena itu, setiap orang Kristen wajib hidup dalm kejujuran. Tuhan sendiri berkata bahwa Ia bergaul erat dengan orang jujur (Ams. 3:32).16 Contoh kasus dalam Alkitab ketika Yohanes pembaptis bertemu dengan beberapa kelompok manusia untuk dibaptis.

'Orang banyak bertanya kepadanya: "Jika demikian, apakah yang harus kami perbuat?" Jawabnya: "Barangsiapa mempunyai dua helai baju, hendaklah ia membaginya

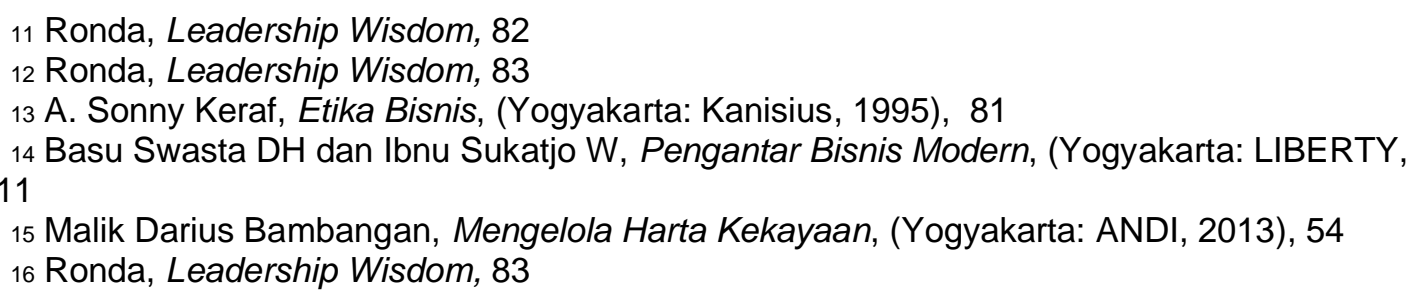


dengan yang tidak punya, dan barangsiapa mempunyai makanan, hendaklah ia berbuat juga demikian." Ada datang juga pemungut-pemungut cukai untuk dibaptis dan mereka bertanya kepadanya: "Guru, apakah yang harus kami perbuat?" Jawabnya: "Jangan menagih lebih banyak dari pada yang telah ditentukan bagimu." Dan prajurit-prajurit bertanya juga kepadanya: "Dan kami, apakah yang harus kami perbuat?" Jawab Yohanes kepada mereka: "Jangan merampas dan jangan memeras dan cukupkanlah dirimu dengan gajimu (Luk.3:10-14)."

Kutipan ayat-ayat tersebut di atas, mewakili tiga lapisan kehidupan sosial masyarakat yang ada saat ini, yakni; 1. Masyarakat biasa, (ay.10-11), 2. Para pengusaha (ay. 12-13), dan 3. Para pegawai dan karyawan (ay.14). Tujuan atau motivasi berbisnis dalam iman Kristen bukanlah hanya untuk menimbun harta sebanyak-banyak lalu menutup diri dengan sesama bahkan melupakan Tuhan. Ethos kerja setiap orang Kristen entah itu sebagai orang biasa yang tidak punya pekerjaan tetap, sebagai pengusaha, dan pegawai atau karyawan mestinya selalu bercermin pada Alkitab. Daniel Ronda menyatakan bahwa, tidak mungkin sebuah bisnis dapat berjalan bila tidak ada keuntungannya. Namun, keuntungan itu hendaknya bukan dijadikan satu-satunya tujuan dalam praktik bisnis sebab, bila demikian, seseorang akan berupaya menghalalkan segala cara untuk mencapai untung ingatlah bahwa setiap perilaku orang percaya itu ada di bawah terang Kristus.17

Jadi motivasi sebagai pelaku bisnis Kristen adalah untuk memuliakan Tuhan melalui segala praktik kerjanya dalam berbisnis maupun dalam gereja dan keluarga. sebagai kesimpulan dalam bagian ini menjadi pedoman orang Kristen dalam menjalankan bisnis adalah; 1 , harus selalu hidup jujur, 2, menjunjung tinggi keadilan,3, tulus dan murni, 4, senantiasa hidup dalam kasih berdasarkan firman Tuhan.

Berbicara tentang kejujuran adalah merupakan hal yang mendasar dalam kehidupan manusia. Dalam kalangan apapun selalu dicari orang yang jujur. Mengapa demikian? Karena orang yang jujur itu tidak pernah berbohong, bertindak apa adanya dan selalu setia serta dapat dipercaya. Lalu bagaimana dengan orang Kristen yang berkecimpung dalam dunia bisnis? Perlukah orang Kristen jujur dalam dunia bisnis atau harus mengikuti situasi dunia politik biar tidak bangkrut kalau terlalu jujur? Justru dalam situasi seperti inilah ciri hidup perilaku Kristen atau etika Kristen harus selalu ada dalam segala situasi. Etika Kristen dalam dunia bisnispun harus selalu hadir. Contoh dalam hal pemberian gaji atau upah kepada karyawan bagi para pemimpin perusahaan, harus selalu berdasarkan aturan. Jangan memberikan gaji di bawah upah minimum. Bila perlu penggajian itu berdasarkan perjanjian awal ketika masuk perusahaan. Hal ini sudah dipaparkan oleh Tuhan Yesus dalam Matius 20:1-16, tentang para pekerja di kebun anggur. Akhir dari perumpamaan berbicara tentang penggajian bagi para pekerja yang diberikan berdasarkan perjanjian awal yakni satu dinar. Baik yang masuk bekerja mulai

17 Ronda, Leadership Wisdom, 83 
pada pagi hari dan yang paling terakhir sore hari, masing-maising mendapat gaji satu dinar sehari sesuai perjanjian awal. Tentang hal ini Daniel Ronda mengutip dua ayat Firman Tuhan yakni Yeremia 22:13 dan Yakobus 5:4. Menurut Burkett yang dikutip oleh Ronda, ada beberapa pedoman dalam menggaji karyawan atau buruh dalam ayat ini. Pertama, Tuhan tidak menghendaki semua orang dibayar dalam jumlah yang sama. Kedua, mereka yang melakukan pekerjaan dengan lebih baik harus dibayar lebih besar. Ketiga, Tuhan sangat menuntut keadalian di dalam membayar upah para karyawan. Keempat, majikan Kristen bertanggung jawab untuk memenuhi kebutuhan minimal para karyawannya.18 Mengenai hal ini J.J.W. Gunning menyatakan, "Akan tetapi kebanyakan orang Kristen yang kaya masih memandang loba terhadap harta kekayaan, tambah lagi ketidakjujuran serta penahanan upah kaum buruh yang mereka tidak bayar." 19 Motivasi yang dibangun di atas kejujuran dalam bisnis adalah merupakan salah satu penentu untuk kemajuan bisnis tersebut.

\section{Tanggung Jawab Pebisinis Kristen}

a. Tanggung jawab sosial

Dalam hal tanggung jawab, orang bisnis dituntut untuk memperhatikan kehidupan masyarakat banyak. Itu artinya bahwa seorang pebisnis atau pengusaha tidak boleh hanya mementingkan diri sendiri dan melupakan kepentingan orang banyak. Dalam Firman Tuhan jelas dikatakan oleh Paulus bahwa, 'Kita, yang kuat, wajib menanggung kelemahan orang yang tidak kuat dan jangan kita mencari kesenangan kita sendiri. Setiap orang di antara kita harus mencari kesenangan sesama kita demi kebaikannya untuk membangunnya' (Rm. 15:1-2). Demikian juga M.D.Bambangan mengatakan bahwa, Manusia sebagai makhluk sosial perlu memperhatikan hidup sesamanya, jangan menjadi parasit atau predator. Sebagai orang percaya yang dikaruniai berkat Tuhan dengan harta kekayaan mempunyai kewajiban atau tanggung jawab terhadap sesama manusia.20

Jadi jika seorang pebisnis Kristen merasa dirinya kuat dalam arti mampu secara materi mereka, maka mestinya membuka mata dan hati untuk kepentingan orang lain juga untuk mengangkat mereka dari keterpurukan ekonominya. Hal ini yang disampaikan oleh Paulus kepada jemaat Galatia untuk bertolong-tolongan menanggung bebanmu karena demikianlah kamu memenuhi hukum Kristus (Gal. 6:2). Janganlah kita jemu-jemu berbuat baik, karena apabila sudah datang waktunya, kita akan menuai, jika kita tidak menjadi lemah. Karena itu, selama masih ada kesempatan bagi kita, marilah kita berbuat baik kepada semua orang, tetapi terutama kepada kawan-kawan kita seiman

${ }_{18}$ Ronda, Leadership Wisdom, 85. Lihat juga Larry Burkett dalam Kunci Sukses Bisnis menurut Alkitab, 254. 
(Gal.6:9-10). Tanggungjawab orang Kristen sebagai pengusaha hendaknya dinyatakan dalam hidup setiap saat dan bukan hanya pada saat-saat tertentu, misalnya baik hanya ketika ia di rumah dan di gereja, di luar itu hidup ala dunia. Douma menyatakan bahwa, panggilan Kitab Suci untuk kelakuan yang baik sangat nyata. Barangsiapa bijaksana dan berakal budi akan menyatakan perbuatannya dengan cara hidup yang baik (Yak.3:13). Kelakuan atau cara hidup orang Kristen yang hidup di antara orang-orang yang bukan Kristen harus demikian, bahwa mereka akan mengubah fitnah menjadi pujian (I Ptr. 2:1).21

Tanggung jawab setiap manusia terhadap sesamanya merupakan panggilan sosial baginya untuk dapat hidup sebagai mahluk sosial. Tangung jawab social tidak hanya melulu kepada materi, namun hal itu lebih kepada bagaimana seorang manusia menjadikan manusia lain dapat setara. A. Sonny Keraf menyatakan,

Sikap tanggung jawab ini tidak dilihat sebagai hal yang bertentangan atau antitese, dari keuntungan. Sebaliknya dilihat sebagai hal yang menunjang usaha mencari keuntungan. Dengan memperhatikan, bahkan mengutamakan kepentingan dan kebutuhan sosial masyarakat, bisnis dapat memperoleh keuntungan untuk menunjang operasinya.22

Demikian juga dengan apa yang dipaparkan oleh Robby I. Chandra bahwa tanggung jawab sosial ini perlu diperhatikan oleh pemeran bisnis karena pertimbangan kelancaran bisnis, serta menjadi tanggung jawab semua lembaga-lembaga untuk membangun masyarakat. Dengan demikian lanjut Chandra bahwa, semestinya pengeluaran dana dan energi untuk pos-pos kemasyarakatan secara bisnis harus dilihat sebagai investasi jangka panjang, terutama untuk investasi citra perusahaan dan bukan sebagai pengeluaran.23 Jadi menjadi tanggung jawab sosial kemasyarakatan bagi pebisnis Kristen untuk tetap memperhatikan lingkungan sekitarnya, jangan bermasa bodoh apalagi menutup diri bagi orang lain.

\section{b. Tanggung Jawab Moral}

Dalam hal ini tanggung jawab moral Kristen yang hidup dalam kasih harus lebih menonjol dalam setiap kehidupan mereka. Dengan demikian cara hidup orang percaya itu akan terlihat tampil beda dengan dunia ini. Sebagai orang Kristen yang diberkati dalam usaha mereka tidak akan merasa rugi jika ia memberikan sebagai hartanya kepada orang lain. Sejalan dengan itu J. Douma menyatakan bahwa walaupun tugas diakonal itu meminta banyak waktu dan uang dari orang percaya, tetapi ia memberikannya dengan gembira. Dan itulah sebabnya lanjut Douma, gaya hidupnya akan bercorak lain daripada

21 Douma, Kelakuan...., 76

22 Keraf, Etika......, 93.

${ }_{23}$ Chandra, Etika Dunia....., 32 
gaya hidup orang dunia, yang mencari kepentingan dan keuntungannya sendiri lebih dahulu.24 Ajaran Alkitab menegaskan kepada setiap kita untuk terus berbuat kasih kepada sesama manusia. Dalam Amsal 3:27-28 berkata, 'Janganlah menahan kebaikan dari pada orang-orang yang berhak menerimanya, padahal engkau mampu melakukannya. Janganlah engkau berkata kepada sesamamu: "Pergilah dan kembalilah, besok akan kuberi," sedangkan yang diminta ada padamu. Ayat ini mengajarkan kepada kita untuk melakukan tindakan kasih kepada sesama menurut apa yang ada pada kita. Demikian jugalah kiranya para pemeran bisnis bila sudah berhasil hendaknya mengingat Tuhan dan sesamanya. Inilah kasih Kristen itu yakni memberikan perhatian kepada orang lain. Brownlee menuturkan bahwa, lawan sikap kasih Kristen itu bukan saja sikap benci melainkan juga sikap masa bodoh terhadap orang lain, yaitu mengabaikannya seola-ola kita tidak bersangkut paut dengannya. Kasih berarti menyamakan diri dengan orang lain dalam kebutuhannya, pengharapannya, kecemasannya, dan kegembiraannya. Kasih berarti menghendaki yang baik untuk orang itu. 25

Inilah inti dari hidup orang percaya yang menjadi garam dan terang di tengah dunia ini. Hidup para pebisnis sebagai orang percaya dalam kancah bisnis sekalipun akan terus tampil beda dengan hidup dalam tatanan etika Kristen berdasarkan firman Tuhan. Yesus berkata; Demikianlah hendaknya terangmu bercahaya di depan orang, supaya mereka melihat perbuatanmu yang baik dan memuliakan Bapamu yang di sorga (Mat. $5: 16) .26$

\section{Prioritas Pebisnis Kristen}

Sebagai pengusaha Kristen seharusnya memiliki prioritas utama dalam hidup mereka. Memiliki skala prioritas akan sangat menunjang kelangsungan hidup bisnis mereka dengan demikian motivasi untuk mendapatkan keuntungan yang sebesarbesarnya akan terwujud. Lalu bagaimana dengan pengusaha Kristen, apakah yang menjadi prioritas mereka? Firman Tuhan jelas dalam Matius 6:33 mengatakan, 'Tetapi carilah dahulu Kerajaan Allah dan kebenarannya, maka semuanya itu akan ditambahkan kepadamu.' Dalam hal apapun sebagai orang Kristen hendaknya mengutamakan Tuhan dalam hidup mereka. Mencari Tuhan terlebih dahulu sebelum melakukan aktivitas usaha kita berarti memberikan ruang pada kerja kuasa Allah untuk mengawal segala usaha kita. Dengan demikian akan selalu beruntung dan berhasil kemanapun kita pergi dan berusaha (Yos. 1:6-9). Malik Darius Bambangan mengutip Myron Rush menyatakan, "Jika Allah tidak diutamakan dalam hidup dan bisnis anda maka anda harus bergantung

24 Douma, Kelakuan....., 79

25 Malcolm Brownlee, Pengambilan Keputusan Etis dan faktor-faktor di dalamnya, (Jakarta: BPK. Gunung Mulia, 2009), 204-205.

26 Lihat juga M.D.Bambangan dalam Mengelola Harta Kekayaan, dalam topik tanggung jawab terhadap orang seiman, halaman 128-130 (Yogyakarta: ANDI, 2013). 
pada sumber daya anda sendiri untuk mencapai keberhasilan dalam bisnis. Namun menjadi sumber utama yang mendatangkan sukses." 27 Jadi bisnis bagi orang yang sudah percaya jelas akan memberi sukses yang gemilang jika ia selalu mendahulukan Tuhan dalam hidup mereka. Maka kita akan setuju dengan apa yang dikatakan Alkitab dalam Amsal 10:22, berkat Tuhanlah yang menjadikan kaya, susah payah tidak akan menambahinya. Artinya bahwa memang Tuhan selalu menuntut umat-Nya untuk bekerja, namun bekerja itu berdasarkan firman Tuhan, bukan berdasarkan kekuatan sendiri. Bagi orang percaya, memiliki harta yang banyak tidaklah salah. Namun akan menjadi salah apabila kekayaan itu menjadi nomor satu dalam hidup orang itu. Malcolm Brownlee menyatakan, Harta benda yang dikaruniakan kepada manusia oleh Allah dan perlu diterima dan dipergunakan dengan rasa syukur. Namun harta benda itu berbahaya menjadi tujuan utama. Walaupun seorang berlimpah-limpah hartanya, hidupnya tidaklah tergantung pada kekayaannya itu (Luk.12:15).28

Dari apa yang dijelaskan di atas memberi konklusi bahwa bisnis itu tidaklah salah dan boleh dilakukan asalkan tetap dalam terang kebenaran firman Tuhan. Saya setuju dengan apa yang dipaparkan oleh Daniel Ronda yang menguti E.G.Singgih, bahwa, hal yang penting bagi pelaku bisnis Kristen adalah, 1. Setiap pelaku bisnis hendaknya memiliki hati nurani, 2. Hendaknya ia peka terhadap masalah-masalah sosial yang ditimbulkan dalam bisnisnya, 3. Hendaknya ia melayani sesamanya.29 Yang menjadi pertanyaan sekarang adalah bagaimanakah sikap dan perilaku pelaku bisnis Kristen sehingga dalam upaya mengejar keuntungan, namun tetap setia pada kebenaran firman Tuhan.

\section{Hasil}

Di atas telah dipaparkan bagaimana sikap hidup orang Kristen dalam melaksanakan bisnis. Tentunya dalam pembahasan itu membahas akan bagaimana kehidupan para pebisnis untuk berbisnis berdasarkan firman Tuhan. Akan terasa timpang jika tulisan ini hanya memaparkan dari cara berusaha dalam bisnis, tetapi melupakan bagaimana cara hidup pebisnis ketika berhasil dalam usahanya. Berikut ini akan dipaparkan bagaimana tindakan mereka ketika berhasil.

\section{Memuliakan Nama Tuhan}

Dalam Amsal 3:9-10 menganjurkan kepada setiap orang percaya untuk memuliakan Tuhan dengan hartanya. Sikap hidup orang percaya dalam memuliakan Tuhan adalah dengan ucapan syukur. Bagaimana ucapan syukur itu dilaksanakan adalah

27 Bambangan, Mengelola...., 54. Lihat juga Myron Rush, Tuhan Penguasa Dunia Perniagaan, (Jakarta: Immanuel, 1990),108

28 Brownlee., Pengambilan Keputusan....,158

29 Ronda, Leadership....., 84 
dengan memberikan persembahan syukur kepada Tuhan. Ruth F.Selan menyatakan, "Persembahan yang berkenan kepada Tuhan adalah memberi dengan suka cita dan kerelaan hati. Alasan untuk bersukacita ialah karena hal itu merupakan kesempatan untuk memberi kepada Tuhan."30 Kesusksesan dalam dunia bisnis memang tidak diraih dengan gampang, melainkan dengan berbagai daya dan upaya. Namun hal itu tidak boleh menjadi alasan bagi pebisnis untuk tidak memuliakan Tuhan. Hidup yang penuh dengan ucapan syukur tersebut merupakan perwujudan iman yang memuliakan nama Tuhan. Jadi mengucap syukur kepada Tuhan atas segala berkat-Nya itu merupakan cara pengagungan nama-Nya.

\section{Menolong Sesama Manusia}

Bambangan menyatakan bahwa, Manusia tidak dapat hidup sendirian karena manusia adalah makhluk sosial yang membutuhkan satu sama lain. Yang berkesempatan pertama untuk dapat menolong sesama manusia dalam kekurangannya hendaknya jangan menutup mata, melipat tangan, bahkan ongkang kaki sementara yang lain menderita kekurangan.31 Ruth F. Selan menyatakan, Allah memberkati dengan kekayaan dan rupa-rupa bentuk, bukan hanya untuk dinikmati sendiri, melainkan untuk dibagibagikan sebagai tanda kasih kepada Allah dan kepada sesama manusia.32

\section{Mendukung Pekerjaan Tuhan}

Menggunakan kekayaan untuk mendukung pekerjaan Tuhan adalah suatu tindakan positif dari langkah kongkrit seorang yang takut akan Tuhan. Mendukung pekerjaan Tuhan bagi orang percaya yang kaya, hendaknya menjadi dasar motivasi untuk mensyukuri berkat dan kasih setia Tuhan dalam hidup ini. Ruth F. Selan mengatakan, "Pemberian kepada Allah adalah suatu perwujudan ucapan terima kasih kepada-Nya dan sebagai suatu kesempatan dan hak istimewa untuk ambil bagian dalam kelangsungan pekerjaan Tuhan, untuk merebut jiwa dari tangan Iblis kepada tangan Tuhan." 33

4. Hidup Rendah Hati dan sederhana

Menjauhkan diri dari ketamakan, keserakahan adalah sikap yang mau mencukupkan diri dalam segala hal, dan merasa puas dengan apa yang ada untuk dinikmati merupakan bukti syukur orang percaya kepada Sang Pencipta alam semesta. Mencukupkan diri dalam segala hal adalah yang berkenan kepada Tuhan. Rasul Paulus berkata, bahwa asal ada makanan, dan pakaian cukuplah (1 Tim. 6:8). Hal ini juga

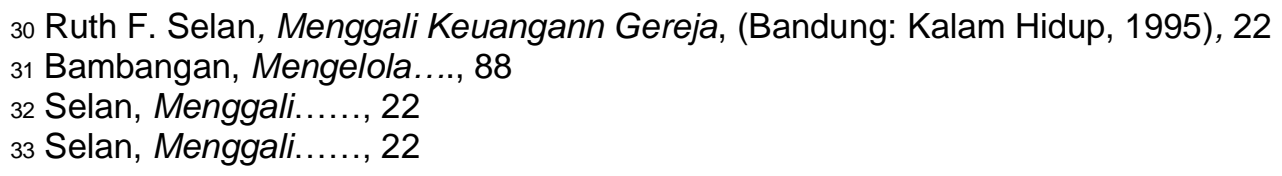


ditegaskan oleh Yohanes Pembaptis pada orang Israel pada saat ia menjalankan misinya sebagai seorang nabi di Israel, Ia menyerukan pertobatan kepada seluruh orang Israel saat itu, dan dengan bukti pertobatan mereka untuk mencukupkan diri dengan apa yang ada pada mereka saat itu, jangan mengambil lebih dari apa yang sudah ditentukan (Luk. 3:10-14).

\section{Tidak Cinta Uang}

Harta benda dan kekayaan diberi sebutan "mamon",di mana mamon dianggap sebagai personifikasi dari yang jahat (Mat.6:24; Luk 16;9). Sikap cinta uang atau materialistis adalah sangat bertentangan dengan Firman Tuhan. Karena akar dari kejahatan ialah Cinta Uang (I Tim.6:10). K. Bertens menyatakan, "Janganlah kamu menjadi hamba uang dan cukupkanlah dirimu dengan apa yang ada padamu (Ibr.13:5)." 34 Sikap cinta uang adalah suatu sikap yang tidak pernah puas dengan apa yang ada padanya walaupun segudang harta, orang itu tetap tidak akan tenang dalam hidupnya. Kekayaan materi yang disertai oleh rasa puas serta syukur yang melimpah akan menjadi basic yang kuat dan ampuh untuk pertahanan iman yang kokoh dan tangguh. Bagi orang percaya dalam segala situasi.

\section{Hidup Arif dan Bijaksana}

Kehidupan yang arif dan bijaksana bagi orang Kristen yang kaya adalah sangat perlu dimana tanpa kearifan dan kebijakan seseorang dalam menggunakannya, dia akan cenderung untuk berjalan sendiri tanpa mau mengerti kehendak Tuhan. Terkadang hidup mereka telah dibutakan oleh ilah zaman ini yaitu mamon. Pernyataan ini mengingatkan kepada orang Kristen yang sudah sukses termasuk para pebisnis kaya supaya mereka jangan bersandar kepada harta bendanya yang nanti pada hari kiamat akan musnah terbakar api. Dan supaya mereka tetap mengandalkan Tuhan dalam hidupnya, dengan demikian Hari Tuhan itu tidak datang seperti api yang menghanguskan baginya. Bagi para pebisnis yang telah sukses kiranya mengelola usahanya tersebut sebagai seorang penatalayan (Steward) atau mitra Allah bagi dunia ini untuk menyatakan Kuasa-Nya yang sanggup memberkati siapa saja yang Ia kehendaki. Kehidupan yang arif dan bijaksana adalah peradaban moral yang baik dan etis. Kebijaksanaan dalam menggunakan berkat Tuhan adalah tidak adanya kelaliman terhadap sesama manusia. Kebijaksanaan dalam bertindak dalam menggunakan kekayaan itu sebagai berkat Tuhan untuk mengasihi sesama terlebih mengasihi Tuhan. Dalam sikap bagaimana orang kaya berlaku arif dan bijaksana adalah dalam hal menghargai sesama manusia sebagai ciptaan Allah. Menghargai sesama manusia, akan mengakibatkan rasa solid yang tinggi mengikis arogansi sosial, menepis struktur dan strata sosial yang berlaku. Orang kaya yang sudah 
mengenal Allah secara benar dan pasti akan memandang harta benda sebagai barang yang nantinya musnah yang tidak kekal dan cenderung mencari harta yang kekal.

\section{Kesimpulan}

Sebagai penutup dalam artikel ini maka penulis akan memberikan kesimpulan sebagai berikut;

Pertama, Kegiatan bisnis tidaklah sejahat atau sekotor seperti pada pandangan segelintir orang. Di atas telah dibahas sedikit tentang hal apa yang menjadi prioritas utama seorang pebisnis Kristen tidak lain adalah Tuhan.

Kedua, Tidak sedikit orang yang sudah sukses dalam bisnis yang terus bercermin pada Alkitab sebagai pedoman hidup dan usaha mereka. Hal ini dikarenakan oleh tindakan para pelaku bisnis tersebut bertindak berdasarkan firman Tuhan. Mereka tidak mementingkan diri sendiri, namun juga memperhatikan orang lain.

Ketiga, Kegiatan bisnis adalah suatu panggilan Allah dalam dunia pekerjaan untuk menatalayani dunia ini menjadi lebih baik untuk kemuliaan Allah. Oleh sebab itu setiap pelaku bisnis hendaknya menjauhkan diri daripada tindakan-tindakan dagang yang merugikan orang lain, tindkan penipuan, ketidak jujuran yang bertentangan dengan Alkiitab. Sebaliknya para pelaku bisnis melakukan mengutamakan Tuhan, kasih, jujur, adil, bijaksana dan rendah hati.

\section{Referensi}

ALKITAB, Jakarta: LAI, 2004

A. Sonny Keraf, Etika Bisnis, (Yogyakarta: Kanisius, 1995)

Alexander Hill, Bisnis yang Benar, (Bandung: Kalam Hidup, 2001)

Anton wuisan, Majalah INTRA, EDISI JUNI-JULI 2002,

Basu Swasta DH dan Ibnu Sukatjo W, Pengantar Bisnis Modern, (Yogyakarta: LIBERTY, 1993).

Daniel Ronda, Leadershiop Wisdom, (Bandung: Kalam Hidup, 2011)

Dorothy Irene Marx, Etika Hamba Tuhan, (Jakarta:Obor Mitra Indonesia, 2001)

J. Douma, Kelakuan Yang Bertanggung Jawab, (Jakarta: BPK.Gunung Mulia, 2007).

J.A.Boersema, Diktat Etika Kristen, pada program pasca sarjana SETIA Jakarta, 2008.

K. Bertens.Pengantar Etika Bisnis, (Yogyakarta: Kanasius, 2000).

Malcolm Brownlee, Pengambilan Keputusan Etis dan faktor-faktor di dalamnya, (Jakarta: BPK. Gunung Mulia, 2009).

Malik Darius Bambangan, Mengelola Harta Kekayaan, (Yogyakarta: ANDI, 2013).

Robby I. Chandra, Etika Dunia Bisnis, (Yogyakarta: Kanasius, 1995)

Ruth F. Selan, Menggali Keuangann Gereja, (Bandung: Kalam Hidup, 1995).

Sumber: http://handyleonardoetikabisnis. blogspot.com/2012/09/pengertian-etikaetika-bisnis-dan. html, disunting oleh Malik Darius Bambangan, pada tgl. 21-8-2014 
Jurnal Luxnos Volume 5 Nomor 2, Edisi Juli-Desember 2019 